\title{
The Role of Country Governance on the Relationship between Firm Governance and Firm Performance: Evidence from Emerging Countries
}

\author{
Soong Yu Qing ${ }^{\mathrm{a}}$, Hooy Chee Wooi ${ }^{\mathrm{b}}$ \& Abdul Hadi Zulkaflic
}

\begin{abstract}
This study examines the moderating effect of country governance on the relationship between firm governance and firm performance in emerging countries. We employ a panel regression model on 21 emerging countries over the period 2007 to 2016. We find that poor firm governance is negatively linked to Tobin's $Q$, but positively linked to return on assets (ROA) and return on equity (ROE), while country governance has a consistent positive moderating effect on all three performance variables. Specific country governance dimensions include voice and accountability, government effectiveness, regulatory quality, the rule of law and control of corruption also have significant positive moderating effects. We further find that only a strong legal environment can compensate for the ineffectiveness of firm governance but not in a weak legal environment and only countries with strong country governance can positively affect firm value.
\end{abstract}

Keywords: Country governance; Emerging countries; Firm performance; Firm governance; Tobin's Q

JEL Classification: G30

\section{Introduction}

The topic of corporate governance has been receiving significant attention since the bankruptcy of Enron and World.com (Holmstrom \& Kaplan, 2003). Prior literature focused on prominent corporate governance practices in developed countries such as the UK (Dahya, McConnell \& Travlos,

a School of Management, Universiti Sains Malaysia, 11800 Gelugor, Penang, Malaysia. Email: soongyuqing@student.usm.my

b Corresponding author. School of Management, Universiti Sains Malaysia, 11800 Gelugor, Penang, Malaysia.Email: cwhooy@usm.my

c School of Management, Universiti Sains Malaysia, 11800 Gelugor, Penang, Malaysia. Email: hadi_zml@usm.my 
2002) and the US (Chhaochharia \& Grinstein, 2007; Cohen, Dey \& Lys, 2008). Findings on corporate governance in developed countries might not be a suitable reference for emerging countries (Arcot \& Bruno, 2007). As capital markets continue to expand and integrate on a global scale, corporate governance becomes much more complex and no longer limited to developed countries. With the rise of large economies such as China and India, corporate governance in emerging countries is slowly gaining more attention from academia (Fan, Wei \& Xu, 2011). Emerging countries are defined as low-income and volatile countries with rapid economic growth and large market returns (Luo, 2002). Along with rapid economic growth, corporate scandals are also rampant in emerging countries. There have been a few infamous scandals in emerging countries, for example, the Satyam Computer Services's accounting fraud (2009) in India (Narayanaswamy, Raghunandan \& Rama, 2012); the Petrobras corruption scandal (2014) in Brazil (Almeida \& Zagaris, 2015); the King Mongkut's Institute of Technology Ladkrabang's financial scandal (2015) in Thailand (Terdpaopong \& Trimek, 2015); the 1 Malaysia Development Berhad's corruption scandal (2015) in Malaysia (Gabriel, 2018); and the vaccine scandal (2018) in China (Han et al., 2019). Consequently, corporate scandals tarnished a firm's reputation, reduced the firm's share price and in some cases forced firms to declare bankruptcy. This prompts the need to review how effectively existing corporate governance mechanisms work in firms operating in emerging countries. Corporate governance research in emerging countries often encounters data limitations due a to lack of transparency in firm disclosure and reporting (Sayari \& Marcum, 2018). This study attempts a multicountry approach based on data available from Datastream to examine the relationship between firm governance and firm value in emerging countries.

Current corporate governance research pinpoints that the effectiveness of corporate governance mechanisms significantly depends on the institutional environment (Aguilera \& Jackson, 2010; Oehmichen, Schrapp \& Wolff, 2017). Firms operating in emerging countries encounter a wide range of potential challenges (Alon \& Hageman, 2017). Emerging countries are known to have poorer private financial markets, more difficulties in accessing financing, more concentrated ownership structures and lower institutional ownership as compared to their Western counterparts (Claessens \& Yurtoglu, 2013). Furthermore, the nature of weak legal systems, unstable political systems, poor investor protection, dynamic economic conditions, 
slow financial development and diverse religions and cultures in emerging countries distinguish them from developed countries (Zattoni \& Cuomo, 2008). Country governance research gained the interest of scholars after La Porta, Lopez-de-Silanes, Shleifer \& Vishny (1997) highlighted that legal origin and national law influences corporate governance. Generally, a lower quality of country governance is observed in emerging countries (Qian, Cao \& Cao, 2018). Inadequate country governance might have an impact on firm governance mechanisms and its effectiveness in achieving better firm valuation (Cumming, Hou \& Wu, 2014; Kumar \& Zattoni, 2016). Therefore, research in the context of emerging countries might be able to provide more understanding on the distinctive institutional environment in emerging countries in terms of weaker institutions from developed countries (Filatotchev, Jackson \& Nakajima, 2013). However, there is only a handful of empirical literature examining country governance especially in emerging countries (Armitage, Hou, Sarkar \& Talaulicar, 2017; Claessens \& Yurtoglu, 2013). Cuomo, Mallin and Zattoni (2016) argued that studies on emerging countries are still limited. As a result, this study aims to fill in the research gap by examining the moderating effect of country governance on the relationship between firm governance and firm value from the perspective of emerging countries. Under this moderating model structure, this study presumes that country governance acts as a moderator of the effect of firm governance and firm value.

Focusing on a big sample of emerging countries, our first objective is to revisit the relationship between firm governance and firm value as documented in the previous literature. We then examine whether there is a moderating effect of country governance on the relationship between firm governance and Tobin's Q. We use corporate governance scores obtained from Datastream as the proxy for firm governance scores (Almaskati, Bird \& Lu, 2020; Duong, Kang \& Salter, 2016). Worldwide Governance Indicator (WGI) obtained from the World Bank is the proxy for country governance score (Chen, Huang \& Chen, 2009; Lim, Makhija \& Shenkar, 2016). We contribute to current literature by incorporating the perspectives of both agency theory and institutitonal theory to explain firm value in emerging countries. The findings suggest that poor firm governance is negatively linked to Tobin's Q, while good firm governance is positively linked to Tobin's Q. In addition, good country governance has a positive moderating effect on firm governance and Tobin's Q. Therefore, policymakers should 
establish a better country governance that firms can benefit from.

The remainder of this study is organised as follows. Section 2 provides a brief discussion on corporate governance theories, existing literature and developing hypotheses. Section 3 explains the data and methodology of this study. Section 4 presents the data analysis and findings. The last section concludes, addresses limitations and suggests future implications.

\section{Literature Review}

\subsection{The theories}

From a theoretical perspective, studies that drawn from agency theory often emphasise firm governance rather than country governance factors (Kumar \& Zattoni, 2013). Agency theory is one of the most dominant theories in corporate governance research (Cuomo et al., 2016; Schiehll \& Martins, 2016). In modern business models, it is common for owners (principals) to hire management teams (agents) to manage the business on behalf of the owners. When ownership and management are separated, the top management might have almost complete discretion in the firm. Thus, the separation of ownership and control creates the need for corporate governance (Shleifer \& Vishny, 1997). Corporate governance is introduced as a tool to resolve the agency problem (Daily, Dalton \& Rajagopalan, 2003; Tsipouri \& Xanthakis, 2004). Conventionally, agency theory suggests that firm governance mechanisms safeguard the best interest of shareholders (Fama \& Jensen, 1983), with the presumption that institutional settings are comparable to the Anglo-Saxon governance system (Ahrens, Filatotchev \& Thomsen, 2011).

On the other hand, the institution is defined as "the rules of the game in a society" that shapes people's interaction (North, 1990). Helmke and Levitsky (2004) further defined institution as both formal and informal rules and procedures that structure social interaction by constraining and enabling its players' behaviour. Institutional theory viewed the presence of the institutional setting surrounding the firms, the economic, political, regulatory, cultural and social rules that, beyond the firm's control, are capable of influencing firms' behaviour and decision making (DiMaggio \& Powell, 1983). Institutional theory highlighted that social rules, expectations, norms and value are sources of pressure on firms to conform (Scott, 2013). 
However, since countries often vary in terms of legal origin, legal system and investor protection (La Porta, Lopez-de-Silanes, Shleifer \& Vishny, 2000), we can expect institutional settings to be different across countries. An efficient view of institutional theory predicts that institutional pressures can force firms to compete for limited resources in order to protect shareholder interests and maximise firm performance (Chen \& Roberts, 2010). In this context, governance effectiveness and the control of corruption practices influence firm valuation (Enikolopov, Petrova \& Stepanov, 2014).

Many recent studies have incorporated both agency theory and institutional theory (Aguilera, Filatotchev, Gospel \& Jackson, 2008; Aguilera \& Jackson, 2003) and demonstrated that the effectiveness of firm governance mechanisms under agency theory may be influenced by institutional settings (Ahrens et al., 2011). The existing literature on the contexts of emerging countries is less than that of developed countries especially from a country governance perspective (Armitage et al., 2017). Firm governance and country governance are operating together and influencing each other, but there has been little research on these two governance mechanisms (Kim \& Ozdemir, 2014; Renders, Gaeremynck \& Sercu, 2010). Therefore, from an agency theory standpoint, we explore the relationship between firm governance and firm value. Whilst, from an efficiency view of institutional theory, we attempt to investigate whether better country governance moderates the relationship between firm governance and firm value in emerging countries contexts.

\subsection{Firm governance and firm value}

Corporate governance is the system of processes and rules by which a firm is controlled and directed. According to agency theory, there is a positive relationship between corporate governance and firm performance. Firms with better firm governance have a lower cost of debt (Lee \& Cho, 2016), attract more capital (Francis, Khurana \& Pereira, 2005) and have higher firm value (Cheung, Connelly, Limpaphayom \& Zhou 2007). However, existing studies documented inconclusive findings in terms of market-based measurement, accounting based measurement, operating performance or stock price (Black \& Khanna, 2007; Black, Shapiro \& Young, 2005; Michelberger, 2016). Michelberger (2016) suggested that the inconsistent findings may be due to a small sample size and short time periods. This may also imply that the value 
of complying with firm governance rules is dependent upon institutional settings (Black \& Khanna, 2007).

Bebchuk and Hamdani (2009) pointed out that firm governance varies between developed and emerging countries. It is different within emerging countries and even different across firms within the same country (Black, Carvalho \& Gorga, 2012). Therefore, a review of former empirical studies on the context of emerging countries is essential. To perform multi-country corporate governance research, scholars generally employed standardised corporate governance indices available through reliable databases. Klapper and Love (2004), who used Credit Lyonnais Securities Asia's (CLSA) database, found that better firm governance is highly associated with better operating performance and higher market valuation from 14 emerging countries. Durnev and Kim (2005) and Morey, Gottesman, Baker and Godridge (2009) presented a positive association between better firm governance and higher market valuations in emerging countries using CLSA's report and Alliance Bernstein's corporate governance rating respectively. Bruno and Claessens (2010) adopted RiskMetrics's report and discovered a positive connection between corporate governance and firm performance. O'Connor, Kinsella and Sullivan (2014) used corporate governance data from Worldscope and found that better-governed firms showed significantly better stock price and firm performance. Drawing from agency theory, this study hypothesise that:

H1: Firm governance has a positive effect towards firm value in emerging countries.

\subsection{Moderating effect of country governance}

Country governance is an external factor that affects the firm beyond the firm's control (Kim \& Ozdemir, 2014). Country governance has an important implication for corporate governance mechanisms and their effectiveness (Armitage et al., 2017). Country governance is a complex paradigm of legal systems, cultural, political, historical, financial and economic development (Denis, 2010). Emerging countries are different from developed countries in terms of low market and informational efficiency, higher volatility and their smaller size (Kumar \& Tsetsekos, 1999). A weak institutional environment comes with weak law enforcement that undermines firms' abilities to compete both locally or internationally and hinders economic development 
(La Porta, Lopez-de-Silanes, Shleifer \& Vishny, 2002).

The pivotal paper by La Porta et al. (1997) highlighted that legal origins and legal systems influence the degree of investor protection across countries. Stronger legal systems have linked to better firm growth and firm performance (La Porta et al., 1997; La Porta, Lopez-de-Silanes, Shleifer \& Vishny, 1998). La Porta et al. (1997) categorised a country's legal origin into common law systems (e.g. English common law) and civil law systems (e.g. French civil law, German civil law and Scandinavian civil law). Countries practicing common law offered better investor rights as compared to civil law countries (Stulz \& Williamson, 2003). Chung, Kim, Park and Sung (2012) also found that firms in common law countries tend to have better corporate governance structures and greater stock market liquidity than firms in civil law countries. Investor protection is a sugar-coated promise without any actual protection if the country has a weak legal infrastructure (Anderson \& Gupta, 2009).

Country-level investor protection is vital in determining the level of firm governance (Aggarwal \& Goodell, 2009). Klapper and Love (2004) and Durnev and Kim (2005) stated that firm governance practices matter more to firm value in countries with weaker investor protection. Bruno and Claessens (2010) found that firms complying to good firm governance improved firm valuation in both weak and strong legal protection countries. This suggests that shareholders tend to benefit from external monitoring especially when firms operate in environments with weaker internal governance mechanisms (Lin, Walker \& Wang, 2020). Doidge, Karolyi and Stulz (2007) showed that country characteristics explain at least $39 \%$ of the variations in corporate governance ratings, while firm characteristics only explain at maximum $22 \%$ of the variations. Also, firms exposed to corruption and poor regulation can mitigate the negative effect and have better firm performance by crosslisting in US exchange markets. This implied that country governance does influence firm performance (Cumming et al., 2014; Doidge, Karolyi \& Stulz, 2004).

Wilson (2016) highlighted the need to understand the interaction between country governance and firm performance. Durnev and Kim (2005) and Judge, Gaur and Muller-Kahle (2010) proposed the legal system as a moderator to examine the effect on committee independence and firm performance. Seifert and Gonenc (2018) used country governance as a moderator and found that strong country governance increased firm cash 
value. The institutional environment has been proposed to moderate the relationship between cash holdings and firm value (Faulkender \& Wang, 2006; Fresard, 2010). Institutional environment has a positive moderating effect on the relationship between corporate governance mechanisms and environmental sustainability (Natalia, Javier \& Matilde, 2014). Therefore, the second hypothesis is proposed as below:

H2: Country governance has a positive moderating effect on the relationship between firm governance and firm value in emerging countries.

\section{Data and Methodology}

\subsection{Sample data}

Similar to the approach of Kim and Lu (2013), we refer to the Morgan Stanley and Capital Group International (MSCI) Emerging Markets Index to determine the emerging countries used in our study. MSCI classified a total of 24 countries as emerging countries including Brazil, Chile, China, Colombia, the Czech Republic, Egypt, Greece, Hungary, India, Indonesia, Korea, Malaysia, Mexico, Pakistan, Philippines, Peru, Poland, Qatar, Russia, Taiwan, Thailand, Turkey, South Africa and United Arab Emirates (MSCI index, 2016). This study focuses on all public listed companies but excludes banks and financial institutions, due to the unique corporate governance in financial firms (Adams \& Mehran, 2003; Gompers, Ishii \& Metrick, 2003). After the filtering process, this study consists of 21 emerging countries. Colombia, Pakistan and Peru were excluded as no data was available from the years 2007 to 2016 .

Following studies conducted by Bruno and Claessens (2010), Doidge et al. (2004), Ducassy and Guyot (2017) and Durnev and Kim (2005), we use market-based measurement, Tobin's $\mathrm{Q}$ as the firm value. Tobin's $\mathrm{Q}$ is computed by the ratio of book value of total assets plus market value of equity less book value of equity, divided by book value of total assets. Tobin's Q is used as a measurement of good management because high Tobin's Q suggests that the firm's managers have produced greater market value from the same assets. Market-based measurement represents the longterm value of a firm and is a more reliable performance measure in corporate governance literature than accounting-based measurements (Siddiqui, 2015). 
Firm governance score (FirmGov) is an independent variable, it is the corporate governance score provided by Datastream, as a standardised score (Z-score) that compares the firms' overall governance framework to all other firms available in the database. FirmGov measures a firm's corporate governance systems and processes, which ensure that its board members and executives act in the best interests of its long-term shareholders.

We include firm age, firm growth, firm leverage and firm size as the control variables (Bhagat \& Black, 2002; Durnev \& Kim, 2005; Klapper \& Love, 2004; Larcker, Richardson \& Tuna, 2007; Wintoki, Linck \& Netter, 2012). Firm age is a control variable because older firms tend to have higher market value (Durnev \& Kim, 2005). Firm leverage is often selected to proxy firms' default risk, where higher leverage indicates greater default risk and poor performance (Larcker et al., 2007). Firm growth captures the market value of equity and is another common control variable (Larcker et al., 2007). Firm size is included as control variable because large firms tend to have greater agency problems and are more difficult to monitor, which then requires stricter governance (Klapper \& Love, 2004).

Country governance score (CountryGov) is the moderating variable in this study. Kaufmann, Kraay and Mastruzzi (2009) standardised data from 35 data sources into six country governance dimensions covering 212 countries, available in the World Bank. There are six components to this country governance score: voice and accountability, political stability and absence of violence, government effectiveness, regulatory quality, rule of law and control of corruption. Voice and accountability indicate freedom, democracy and transparency. When the country environment is more democratic, firms tends to practice democratic procedures, hence their shareholders can voice their opinion more freely, leading to lower agency cost and better firm performance (Chen \& Yang, 2017). Political stability and the absence of violence refers to the possibility that the government will be destabilised or overthrown by unconstitutional, violent means, or terrorism. When the politics of the country is stable, it lessens the uncertainty in operating businesses and leads to better firm governance and firm performance (Ngobo \& Fouda, 2012). Government effectiveness captures the quality, bureaucracy and competence of public services. Better government effectiveness leads to better firm governance and firm performance (González \& García-Meca, 2014). Regulatory quality is the government's ability to enact and execute policies and regulations. Good regulatory quality significantly improves 
firm performance (Jalilian, Kirkpatrick \& Parker, 2007). Rule of law refers to the extent a society abides to the societal rules and protections of rights (La Porta et al., 2000). A strong rule of law enables a better environment for businesses and improves firm governance and firm performance (Nguyen, Locke \& Reddy, 2015). Control of corruption captures the exercise of public power for private gain. Better control of corruption prevents the occurrence of bureaucratic corruption and bribery in doing business.

Each CountryGov indicator ranges from -2.5 to +2.5 , with higher scores indicating better country governance and vice versa. Globerman and Shapiro (2002) are concerned that there is a high correlation between the six governance components. Therefore, this study constructs country governance scores by adding all six country governance components that range between -15.00 and +15.00 to overcome this high correlation, similar to Chen et al., (2009) and Lim et al. (2016). Table 1 presents the definitions and sources of all variables.

Based on the hypothesis presented earlier, panel regression models are proposed as below. Model 1 is developed to examine the relationship between firm governance and Tobin's Q.

$$
\begin{aligned}
\text { Tobin } Q_{i t}= & \alpha_{i t}+\beta_{1} \text { FAge }_{i t}+\beta_{2} \text { FGrowth }_{i t}+\beta_{3} \text { FLeverage }_{i t}+\beta_{4} \text { FSize }_{i t}+ \\
& \beta_{5} \text { FirmGov }_{i t}+\varepsilon_{i t}
\end{aligned}
$$

where Tobin's $\mathrm{Q}_{i t}$ denotes the firm value of firm $i$ at year $t$; FAge ${ }_{i t}$ denotes the natural $\log$ of firm age for firm $i$ at year $t$; FGrowth ${ }_{i t}$ denotes as market to book value for firm $i$ at year $t$; FLeverage ${ }_{i t}$ denotes the firm leverage of firm $i$ at year $t$; FSize ${ }_{i t}$ denotes the natural $\log$ of firm sales for firm $i$ at year $t ;$ FirmGov $_{i t}$ denotes the firm governance score of firm $i$ at year $t$ and $\varepsilon_{i t}$ denotes the error term with the usual distributional assumptions. To examine the influence of country governance on the relationship between firm governance and Tobin's Q, the moderating effect of country governance is incorporated in model 2. 
Table 1: Definitions of variables

\begin{tabular}{ll}
\hline Variables & Definitions \\
\hline Dependent variable & $\begin{array}{l}\text { Tobin's Q computes as the ratio of total assets plus market value } \\
\text { of equity less book value of equity, divided by total assets. Source } \\
\text { from Datastream. }\end{array}$ \\
\hline Control variables & $\begin{array}{l}\text { Firm age measures using the company age. Source from } \\
\text { FAge }\end{array}$ \\
FGrowth & $\begin{array}{l}\text { Firm growth measures using market value of equity divided by } \\
\text { book value of common equity. Source from Datastream. }\end{array}$ \\
FLeverage & $\begin{array}{l}\text { Firm leverage measures using total debt divided by total assets } \\
\text { where total debt is defined as long term loans plus short-term loans. }\end{array}$ \\
Source from Datastream. \\
Firm size is measured using natural log of firm sales. Source from \\
Datastream.
\end{tabular}




\subsection{Empirical model}

$$
\begin{aligned}
\text { Tobin } Q_{i t}= & \alpha_{i t}+\beta_{1} \text { FAge }_{i t}+\beta_{2} \text { FGrowth }_{i t}+\beta_{3} \text { FLeverage }_{i t}+\beta_{4} \text { FSize }_{i t}+ \\
& \beta_{5} \text { FirmGov }_{i t}+\beta_{6} \text { CountryGov }_{j t}+\beta_{7}\left(\text { FirmGov }_{i t} * \text { CountryGov }_{j t}\right) \\
& +\varepsilon_{i j t}
\end{aligned}
$$

where CountryGov ${ }_{j t}$ denotes the country governance of county $j$ at year $t$, Lastly, $\varepsilon_{i j t}$ denotes the error term with the usual distributional assumptions.

\section{Results and Discussions}

\subsection{Descriptive statistics analysis}

Table 2 shows country statistics in terms of legal system (common law and civil law), origin of legal system (English, French and German), number of firm observations, country governance score, voice and accountability, political stability and absence of violence, government effectiveness, regulatory quality, rule of law and control of corruption for 21 emerging countries. There are 17 emerging countries following the civil law system that either originated from French or German and only four countries following the English common law. There is a total of 5082 observations from year 2007 to 2016. Political stability and absence of violence is the only country governance dimension with a negative mean.

Table 3 presents the descriptive statistics. To reduce the influence of outliers, this study winsorised data at $1 \%$ to $99 \%$ (Ammann, Oesch \& Schmid 2011; Fauver, Hung, Li \& Taboada, 2017). Tobin's Q has a mean value of 1.844 , indicates that firms have good market valuation relative to their book value. The mean of FirmGov is 0.293 and ranging from 0.011 to 0.954 . This range indicates that there are firms having quite poor firm governance. The mean of CountryGov is 1.168 ranging from -5.684 to 7.317 . Table 4 shows the correlation analysis. The correlation coefficient ranging from -0.229 to 0.735 . This suggests that multicollinearity is not a concern. In addition, mean VIF of 1.450 in Panel B also suggests that there are no major correlation problems among the variables. 
Table 2: Sample characteristics for 21 emerging countries

\begin{tabular}{|c|c|c|c|c|c|c|c|c|c|c|}
\hline Country & $\begin{array}{c}\text { Legal } \\
\text { System }\end{array}$ & $\begin{array}{c}\text { Origin } \\
\text { of Legal } \\
\text { System }\end{array}$ & $\mathbf{N}$ & CountryGov & VA & PS & GE & RQ & $\mathbf{R L}$ & $\mathrm{CC}$ \\
\hline Brazil & Civil & French & 448 & -0.034 & 0.485 & -0.166 & -0.126 & -0.001 & -0.069 & -0.157 \\
\hline Chile & Civil & French & 155 & 6.878 & 1.050 & 0.471 & 1.181 & 1.448 & 1.321 & 1.406 \\
\hline China & Civil & German & 505 & -3.096 & -1.646 & -0.552 & 0.183 & -0.256 & -0.426 & -0.399 \\
\hline $\begin{array}{l}\text { Czech } \\
\text { Republic }\end{array}$ & Civil & German & 26 & 5.509 & 1.017 & 1.017 & 0.956 & 1.134 & 1.035 & 0.351 \\
\hline Egypt & Civil & French & 37 & -4.834 & -1.109 & -1.376 & -0.674 & -0.572 & -0.466 & -0.637 \\
\hline Greece & Civil & French & 104 & 2.239 & 0.778 & -0.058 & 0.443 & 0.572 & 0.523 & -0.020 \\
\hline Hungary & Civil & German & 23 & 3.863 & 0.718 & 0.705 & 0.606 & 0.911 & 0.629 & 0.294 \\
\hline India & Common & English & 505 & -1.635 & 0.426 & -1.137 & -0.041 & -0.396 & -0.053 & -0.434 \\
\hline Indonesia & Civil & French & 189 & -1.992 & 0.081 & -0.592 & -0.172 & -0.236 & -0.489 & -0.584 \\
\hline Korea & Civil & German & 547 & 4.587 & 0.695 & 0.263 & 1.144 & 0.998 & 0.981 & 0.506 \\
\hline Malaysia & Common & English & 267 & 2.053 & -0.417 & 0.126 & 0.999 & 0.652 & 0.495 & 0.198 \\
\hline Mexico & Civil & French & 185 & -1.177 & 0.051 & -0.749 & 0.231 & 0.359 & -0.512 & -0.558 \\
\hline Philippines & Civil & French & 110 & -2.097 & 0.053 & -1.171 & 0.086 & -0.090 & -0.434 & -0.540 \\
\hline Poland & Civil & German & 129 & 4.972 & 1.015 & 0.897 & 0.703 & 0.984 & 0.758 & 0.615 \\
\hline Qatar & Civil & German & 23 & 3.251 & -1.119 & 1.008 & 0.874 & 0.656 & 0.837 & 0.996 \\
\hline Russia & Civil & French & 233 & -4.412 & -0.992 & -0.902 & -0.332 & -0.382 & -0.790 & -1.015 \\
\hline South Africa & Common & English & 536 & 1.325 & 0.619 & -0.093 & 0.348 & 0.332 & 0.125 & -0.005 \\
\hline Taiwan & Civil & German & 767 & 6.057 & 0.881 & 0.870 & 1.255 & 1.205 & 1.080 & 0.767 \\
\hline Thailand & Common & English & 155 & -1.835 & -0.696 & -1.117 & 0.284 & 0.230 & -0.140 & -0.397 \\
\hline Turkey & Civil & French & 114 & -0.763 & -0.243 & -1.194 & 0.309 & 0.343 & 0.023 & -0.001 \\
\hline $\begin{array}{l}\text { United Arab } \\
\text { Emirates }\end{array}$ & Civil & French & 24 & 3.479 & -1.016 & 0.739 & 1.238 & 0.782 & 0.608 & 1.129 \\
\hline Total & & & 5,082 & 1.168 & 0.171 & -0.161 & 0.485 & 0.387 & 0.250 & 0.037 \\
\hline
\end{tabular}

Notes: The legal system and origin of legal system of emerging countries is referred to La Porta, Lopez-de-Silanes \& Shleifer (2008). The total number of firm observations (N) in a country, the country governance score (CountryGov), voice and accountability (VA), political stability and absence of violence (PS), government effectiveness (GE), regulatory quality (RQ), rule of law and control of corruption (CC) are presented. These country governance scores are constructed by World Bank (Kaufmann et al., 2009). The sample period is from year 2007-2016. 
Table 3: Descriptive statistics of variables

\begin{tabular}{lcccccccc}
\hline \multicolumn{1}{c}{ Variable } & Obs & Mean & $\begin{array}{r}\text { Std. } \\
\text { Dev. }\end{array}$ & Min & p25 & p50 & p75 & Max \\
\hline Tobin Q & 5,082 & 1.844 & 1.379 & 0.560 & 1.047 & 1.364 & 2.095 & 8.890 \\
FAge & 5,082 & 3.426 & 0.763 & 1.386 & 2.890 & 3.497 & 3.989 & 4.868 \\
FGrowth & 5,082 & 2.882 & 3.518 & 0.110 & 1.120 & 1.810 & 3.190 & 24.720 \\
FLeverage & 5,082 & 0.304 & 0.167 & 0.022 & 0.182 & 0.288 & 0.407 & 0.782 \\
FSize & 5,082 & 1.188 & 1.355 & -2.465 & 0.257 & 1.170 & 2.132 & 4.568 \\
FirmGov & 5,082 & 0.293 & 0.251 & 0.011 & 0.083 & 0.215 & 0.464 & 0.954 \\
CountryGov & 5,082 & 1.168 & 3.495 & -5.684 & -1.769 & 1.104 & 4.669 & 7.319 \\
\hline
\end{tabular}

Notes: This table reports the number of observations, mean, standard deviation, minimum, $25^{\text {th }}, 50^{\text {th }}$ and $75^{\text {th }}$ percentiles and maximum value of the variables. Tobin's $\mathrm{Q}$, firm age, firm growth, firm leverage and firm size are winsorised at 1\%-99\% levels to minimize the effect of outliers. The sample period is from 2007 to 2016 .

Table 4: Correlation and collinearity diagnostics

\begin{tabular}{|c|c|c|c|c|c|c|c|}
\hline \multicolumn{8}{|c|}{ Panel A: Pearson correlation } \\
\hline & 1 & 2 & 3 & 4 & 5 & 6 & 7 \\
\hline 1. Tobin's Q & 1.000 & & & & & & \\
\hline 2. FAge & 0.039 & 1.000 & & & & & \\
\hline 3. FGrowth & 0.735 & 0.043 & 1.000 & & & & \\
\hline 4. FLeverage & -0.027 & -0.022 & 0.165 & 1.000 & & & \\
\hline 5. FSize & -0.220 & 0.009 & -0.146 & 0.026 & 1.000 & & \\
\hline 6. FirmGov & 0.026 & 0.086 & 0.058 & -0.026 & 0.048 & 1.000 & \\
\hline 7. CountryGov & -0.135 & 0.109 & -0.126 & -0.125 & -0.107 & -0.229 & 1.000 \\
\hline
\end{tabular}

Panel B: Collinearity diagnostics (Variance inflation and tolerance factors)

\begin{tabular}{lcc}
\hline Variables & VIF & Tolerance \\
\hline 1. Tobin's Q & 2.390 & 0.419 \\
2. FAge & 1.030 & 0.971 \\
3. FGrowth & 2.360 & 0.423 \\
4. FLeverage & 1.100 & 0.906 \\
5. FSize & 1.070 & 0.931 \\
6. FirmGov & 1.080 & 0.928 \\
7. CountryGov & 1.140 & 0.879 \\
Mean VIF & 1.450 & \\
\hline
\end{tabular}

Notes: This table presents the correlation and collinearity diagnostics. Tobin's Q, firm age, firm growth, firm leverage and firm size are winsorised at 1\%-99\% levels to minimize the effect of outliers. The sample period is from 2007 to 2016. 


\subsection{Regression analysis}

\subsubsection{The effect of firm governance and firm value}

The panel regression analysis is reported in Table 5. With the full sample, we document a surprising result where firm governance is negative and statistically significant on Tobin's Q. This is rather surprising even though Munisi and Randøy (2013) also shared a similar result. We suspect that the results could be due to these emerging markets having a large proportion of poorly governed firms. Indeed, when we refer to the descriptive statistics in Table 3, we can see that the firm governance score (FirmGov) is positively skewed with a mean of 0.293 and medium of 0.215 and the 75 percentile of 0.464 , less than half the perfect score of 1 . This shows that the majority of the firms in our sample in the emerging markets are having very poor firm governance performance. Firms with weaker firm governance show lower performance (Brown \& Caylor, 2004). When the interest of shareholders and investors are not protected, poorly governed firms reflected lower firm value. This finding is also consistent with previous empirical research such as Achim, Borlea \& Mare (2016) and Sami, Wang \& Zhou (2011).

Thus, we decided to conduct a subsample analysis to verify if this could be the case. We extracted the top 30 highest and lowest firm governance scores and estimated the model. ${ }^{1}$ The results shows that indeed the Top-30 firms show a positive and significant firm value and firm governance values whereas the Bottom-30 firms display a negative significant relationship.

\subsubsection{The moderating effect of country governance on the relationship between firm governance and firm value}

Table 6 presents the fixed effect regression including both country and year fixed effect. Model 1 shows that country governance has a positive and significant effect on firm value, implying that better country governance improved firm valuation, consistent with Kumar and Zattoni (2013). Model 2 allows us to infer on $\mathrm{H} 2$ where the moderating term of country governance is shown to be positive and significant at the $1 \%$ level. This implies that good country governance can mitigate the negative influence of poor firm governance (Nguyen et al., 2015; Qian et al., 2018). Models 3 to 8 further explore the moderating effect of each specific components of country 
Table 5: The effect of firm governance on firm value

\begin{tabular}{llll}
\hline & All firms & Bottom 30 firms & Top 30 firms \\
\hline FAge & $-0.5518^{* * *}$ & -0.2227 & $-2.6089^{* * *}$ \\
FGrowth & $(0.0759)$ & $(0.6393)$ & $(0.3398)$ \\
& $0.1304^{* * *}$ & $0.1231^{* * *}$ & $0.1714^{* *}$ \\
FLeverage & $(0.0051)$ & $(0.0396)$ & $(0.0424)$ \\
& $-1.2278^{* * *}$ & 0.004 & $0.0281^{* *}$ \\
FSize & $(0.1147)$ & $(0.0096)$ & $(0.0093)$ \\
& 0.0137 & 0.2324 & $0.4226^{* *}$ \\
FirmGov & $(0.0262)$ & $(0.2810)$ & $(0.1232)$ \\
& $-0.1587^{*}$ & $-0.1663 * * *$ & $0.0077^{* *}$ \\
Constant & $(0.0811)$ & $(0.0597)$ & $(0.0026)$ \\
& $3.7621^{* * *}$ & -0.8888 & $4.3457^{*}$ \\
Year & $(0.2502)$ & $(5.8814)$ & $(1.6904)$ \\
Country & & & \\
Observations & Yes & Yes & Yes \\
$\mathrm{R}^{2}$ & Yes & Yes & Yes \\
\hline
\end{tabular}

Notes: Table 5 presents fixed effect regression estimation for firm governance and firm value. The Tobin's Q, firm age, firm growth, firm leverage and firm size are winsorised at $1 \%-99 \%$ levels to minimize the effect of outliers. The sample period is from 2007 to 2016. The number in parentheses are standard errors. ***,**,* denote significance of $1 \%, 5 \%$ and $10 \%$ significant levels, respectively.

governance. In model 3, the moderating term of voice and accountability is found to be positive and significant at $1 \%$ level to firm value. This implies that firms are more inclined to practice democratic procedures when the country environment is more democratic. The better aligned interests of shareholders and managers can lower the agency costs which in turn improve firm governance and firm value (Chen \& Yang, 2017). In model 4 , the moderating term political stability and absence of violence does not have a statistically significant relationship with Tobin's Q. This may be attributable to the unstable political condition in emerging countries as shown in Table 1. An unstable political environment hinders firms to access capital and investment easily which may lead to lower firm value. 
In model 5, the moderating terms government effectiveness is positive and statistically significant at the $10 \%$ level. This implies that better government effectiveness reduces lengthy bureaucratic procedures, thus improves firm governance and firm value (González \& García-Meca, 2014). In model 6, the moderating term regulatory quality indicates a positive and significant $10 \%$ level on Tobin's Q. Better regulatory quality ensures management complies with regulations, hence diminishes the effect of poor firm governance and generates better firm value (La Porta et al., 2000). In model 7, the moderating term rule of law is positive and statistically significant at the $5 \%$ level. Rule of law is essential in shaping firm governance either directly or indirectly (Chen \& Yang, 2017). The positive sign implies that stronger rule of law creates better investors protection and reduces the influence of poor firm governance and improves firm value (Nguyen et al., 2015). In model 8 , the moderating term of control of corruption is positive and statistically significant at the $1 \%$ level. This indicates that better control of corruption lessens the effect of poor firm governance. Stricter control of corruption increases both domestic and foreign investments, reduces firm's operating costs ultimately improves firm competitiveness and firm value (Gaviria, 2002; De Rosa, Gooroochurn \& Gorg, 2015).

Overall, our results indicate that country governance has a positive moderating effect on the relationship between firm governance and Tobin's Q, which lends empirical support to H2. This is consistent with previous studies that better country governance improves firm performance especially in emerging markets (Bruno \& Claessens, 2010). Additionally, country governance components namely better voice and accountability, government effectiveness, regulatory quality, rule of law and control of corruption also positively moderate the relationship between firm governance and firm value. This aligned with institutional theory where a strong institutional environment is capable of influencing firms to practice good governance in order to enhance firm value. 
Table 6: Moderating effect of country governance on the relationship between firm governance and firm value

\begin{tabular}{|c|c|c|c|c|c|c|c|c|}
\hline & 1 & 2 & 3 & 4 & 5 & 6 & 7 & 8 \\
\hline FAge & $\begin{array}{l}-0.6195 * * * \\
(0.0700)\end{array}$ & $\begin{array}{l}-0.0493 \\
(0.2235)\end{array}$ & $\begin{array}{l}0.0168 \\
(0.2298)\end{array}$ & $\begin{array}{l}-0.0594 \\
(0.2198)\end{array}$ & $\begin{array}{l}-0.1116 \\
(0.2274)\end{array}$ & $\begin{array}{l}-0.0599 \\
(0.2185)\end{array}$ & $\begin{array}{l}-0.0417 \\
(0.2213)\end{array}$ & $\begin{array}{l}-0.0768 \\
(0.2213)\end{array}$ \\
\hline FGrowth & $\begin{array}{l}0.1293 * * * \\
(0.0051)\end{array}$ & $\begin{array}{l}0.1315 * * * \\
(0.0233)\end{array}$ & $\begin{array}{l}0.1323 * * * \\
(0.0234)\end{array}$ & $\begin{array}{l}0.1319 * * * \\
(0.0234)\end{array}$ & $\begin{array}{l}0.1313^{* * *} \\
(0.0233)\end{array}$ & $\begin{array}{l}0.1319 * * * \\
(0.0233)\end{array}$ & $\begin{array}{l}0.1324 * * * \\
(0.0235)\end{array}$ & $\begin{array}{l}0.1317^{* * *} * \\
(0.0233)\end{array}$ \\
\hline FLeverage & $\begin{array}{l}-1.2182 * * * \\
(0.1148)\end{array}$ & $\begin{array}{l}-1.1146^{* * * *} \\
(0.2415)\end{array}$ & $\begin{array}{l}-1.1326^{* * * *} \\
(0.2405)\end{array}$ & $\begin{array}{l}-1.1365^{* * * *} \\
(0.2455)\end{array}$ & $\begin{array}{l}-1.1379^{* * *} \\
(0.2459)\end{array}$ & $\begin{array}{l}-1.1219 * * * \\
(0.2434)\end{array}$ & $\begin{array}{l}-1.1263^{* * *} \\
(0.2449)\end{array}$ & $\begin{array}{l}-1.1100^{* * *} \\
(0.2410)\end{array}$ \\
\hline FSize & $\begin{array}{l}0.0005 \\
(0.0265)\end{array}$ & $\begin{array}{l}0.0236 \\
(0.0580)\end{array}$ & $\begin{array}{l}0.0240 \\
(0.0578)\end{array}$ & $\begin{array}{l}0.0238 \\
(0.0589)\end{array}$ & $\begin{array}{l}0.0219 \\
(0.0572)\end{array}$ & $\begin{array}{l}0.0171 \\
(0.0584)\end{array}$ & $\begin{array}{l}0.0303 \\
(0.0574)\end{array}$ & $\begin{array}{l}0.0263 \\
(0.0573)\end{array}$ \\
\hline FirmGov & & $\begin{array}{l}-0.0575 \\
(0.1311)\end{array}$ & $\begin{array}{l}-0.0201 \\
(0.1340)\end{array}$ & $\begin{array}{l}-0.0966 \\
(0.1424)\end{array}$ & $\begin{array}{l}-0.1932 \\
(0.1656)\end{array}$ & $\begin{array}{l}0.0232 \\
(0.1205)\end{array}$ & $\begin{array}{l}-0.0726 \\
(0.1341)\end{array}$ & $\begin{array}{l}0.0300 \\
(0.1237)\end{array}$ \\
\hline CountryGov & $\begin{array}{l}0.0387 * * \\
(0.1927)\end{array}$ & $\begin{array}{l}0.0006 \\
(0.0346)\end{array}$ & & & & & & \\
\hline FirmGov*CountryGov & & $\begin{array}{l}0.0939 * * * \\
(0.0350)\end{array}$ & & & & & & \\
\hline VA & & & $\begin{array}{l}-0.1319 \\
(0.1923)\end{array}$ & & & & & \\
\hline FirmGov*VA & & & $\begin{array}{l}0.3320 * * * \\
(0.1281)\end{array}$ & & & & & \\
\hline PS & & & & $\begin{array}{l}-0.0352 \\
(0.1349)\end{array}$ & & & & \\
\hline FirmGov*PS & & & & $\begin{array}{l}0.2276 \\
(0.1885)\end{array}$ & & & & \\
\hline GE & & & & & $\begin{array}{l}0.0632 \\
(0.1305)\end{array}$ & & & \\
\hline FirmGov*GE & & & & & $\begin{array}{l}0.3855^{*} \\
(0.2120)\end{array}$ & & & \\
\hline RQ & & & & & & $\begin{array}{l}0.0455 \\
(0.0991)\end{array}$ & & \\
\hline FirmGov*RQ & & & & & & $\begin{array}{l}0.2578^{*} \\
(0.1529)\end{array}$ & & \\
\hline RL & & & & & & & $\begin{array}{l}-0.2016 \\
(0.1597)\end{array}$ & \\
\hline FirmGov*RL & & & & & & & $\begin{array}{l}0.4769 * * \\
(0.1912)\end{array}$ & \\
\hline $\mathrm{CC}$ & & & & & & & & $\begin{array}{l}-0.1089 \\
(0.1339)\end{array}$ \\
\hline FirmGov*CC & & & & & & & & $\begin{array}{l}0.6699 * * * \\
(0.2143)\end{array}$ \\
\hline Constant & $\begin{array}{l}3.9182 * * * \\
(0.4618)\end{array}$ & $\begin{array}{l}2.5854 * * * \\
(0.7152)\end{array}$ & $\begin{array}{l}2.4042 * * * \\
(0.7487)\end{array}$ & $\begin{array}{l}2.6534 * * * \\
(0.7114)\end{array}$ & $\begin{array}{l}2.7782 * * * \\
(0.7188)\end{array}$ & $\begin{array}{l}2.6379 * * * \\
(0.7114)\end{array}$ & $\begin{array}{l}2.6188 * * * \\
(0.7132)\end{array}$ & $\begin{array}{l}2.6752 * * * \\
(0.7171)\end{array}$ \\
\hline Year & Yes & Yes & Yes & Yes & Yes & Yes & Yes & Yes \\
\hline Country & Yes & Yes & Yes & Yes & Yes & Yes & Yes & Yes \\
\hline Observations & 5082 & 5082 & 5082 & 5082 & 5082 & 5082 & 5082 & 5082 \\
\hline $\mathrm{R}^{2}$ & 0.1753 & 0.2199 & 0.2197 & 0.2174 & 0.2190 & 0.2184 & 0.2190 & 0.2211 \\
\hline
\end{tabular}

Notes: This table presents the moderating effect of country governance (CountryGov) on the relationship of firm governance (FirmGov) and firm value (Tobin's Q) in emerging countries using fixed effect regression estimation. The country governance score (CountryGov), voice and accountability (VA), political stability and absence of violence (PS), government effectiveness (GE), regulatory quality (RQ), (5) rule of law and control of corruption (CC) are obtained from World Bank. Tobin's Q, firm age, firm growth, firm leverage and firm size are winsorised at 1\%-99\% levels in order to minimize the effect of outliers. The sample period is from 2007 to 2016. The numbers in parentheses are standard errors. $* * *, * * *$ denote significance of $1 \%, 5 \%$ and $10 \%$ significant levels, respectively. 


\subsection{Robustness check}

We assess the robustness of our results for both of the hypotheses by using return on assets (ROA) and return on equity (ROE) as alternative proxies for firm value. ROA is defined as the ratio of net income to total assets while ROE is defined as the ratio of net income to book value on equity. Both data were sourced from Datastream. The result reported in Table 7 shows that firm governance has a positive and significant effect when ROA and ROE are being used as dependent variables. This result is contradicting with the negative estimate reported in Table 5 for the full sample. The positive estimate is consistent with the $\mathrm{H} 1$ showing that the profitability measure provides closer proxy for firm performance as compared to Tobin's Q as Tobin's Q represents a firm's investment and growth opportunities, including those generated from management and corporate governance (Bozec \& Bozec, 2011). Thus, Tobin's Q is not that straightforward measure for performance as compared to ROA and ROE. As opposite to H1, the results on $\mathrm{H} 2$ is more consistent with those in the analysis reported in Table 6 , as the moderating term also has a positive and significant effect on firm performance.

\section{Further Issue I: Subsample regression based on legal system}

Since firm governance varies across legal systems and it exerts differential effect on firm performance (Anderson \& Gupta, 2009), we perform subsample analysis based on legal systems (common law and civil law) to further explain the moderating effect of country governance. Referring to $\mathrm{La}$ Porta et al. (2008), we conduct subsample analysis based on legal systems (i.e. common law and civil law) and the origin of the legal system (i.e. English common law, German civil law and French civil law). The result is reported in Table 8 . The results show country governance has an insignificant moderating effect in English common law and French civil law countries, but a positive and significant moderating effect in civil law countries and German civil law. Civil law countries are often argued to have weaker legal environments than common law countries (La Porta et al., 2002) but we find that the country governance score of civil law countries is positive (1.319), whilst, the country governance score of common law countries is negative (-0.023). In our sample, the firm behaviour appears to be contradict the 
Table 7: Robustness check

\begin{tabular}{lllll}
\hline & ROA & ROE & ROA & ROE \\
\hline Fage & -0.6522 & 0.3213 & 0.9733 & -20.4349 \\
& $(0.2411)$ & $(0.2816)$ & $(0.4687)$ & $(0.1124)$ \\
FGrowth & $-0.2361^{* * *}$ & $2.2117^{* * *}$ & $-0.2317^{* *}$ & $3.0627^{*}$ \\
& $(0.0043)$ & $(0.0000)$ & $(0.0415)$ & $(0.0712)$ \\
FLeverage & $70.9391^{* * *}$ & $-11.1023^{* * *}$ & $77.1411^{* * *}$ & $-87.3771^{* *}$ \\
& $(0.0000)$ & $(0.0000)$ & $(0.0000)$ & $(0.0351)$ \\
FSize & $1.1050^{* * *}$ & $0.4825^{* * *}$ & $0.7033^{*}$ & $19.3776^{* *}$ \\
FirmGov & $(0.0006)$ & $(0.0032)$ & $(0.0798)$ & $(0.0393)$ \\
& $1.3213^{* *}$ & $1.2213^{*}$ & 1.1581 & 5.5675 \\
CountryGov & $(0.0385)$ & $(0.0694)$ & $(0.1336)$ & $(0.4630)$ \\
& & & 0.5239 & 7.4390 \\
FirmGov*CountryGov & & & $(0.6308)$ & $(0.4850)$ \\
& & & $0.3990^{*}$ & $2.2262^{*}$ \\
Constant & & & $(0.0710)$ & $(0.0784)$ \\
& & & -1.3438 & $76.3531^{* *}$ \\
R ${ }^{2}$ & $9.2812^{* * *}$ & $15.5391^{* * * *}$ & $(0.7337)$ & $(0.0413)$ \\
Year & $(0.0013)$ & 0.0000 & & \\
\hline
\end{tabular}

Notes: This table reports the robustness test using alternate proxies for firm performance. ROA is measured as the ratio of net income to total assets. ROE is measured as the ratio of net income to book value on equity. ROA, ROE, firm age, firm growth, firm leverage and firm size are winsorised at $1 \%-99 \%$ levels to minimize the effect of outliers. The sample period is from 2007 to 2016 . The numbers in parentheses are p-values. ***, **, * denote significance of $1 \%, 5 \%$ and $10 \%$ significant levels, respectively.

current notion as civil law countries have shown to have better institutional settings than common law countries. This may be the reason why firms operating in emerging countries with civil law systems have a significantly positive Tobin's Q as compared to emerging countries with common law systems. Earlier studies proposed that investors are best protected in English common law but are somewhat protected in German civil law and most 
vulnerable in French civil law (Maher \& Andersson, 2000). Nonetheless, in our sample the average country governance score for German civil law and French civil law countries are 3.592 and -0.271 , respectively. This implies that emerging countries under German civil law have an unexpectedly superior institutional environment than those under French civil law. Our result suggests that stronger legal environments (German civil law) can compensate for the ineffectiveness of firm governance but not in the case of weaker legal environments (French civil law).

Table 8: Subsample regression based on legal system and origin of legal system

\begin{tabular}{lllll}
\hline & Common/English & Civil & German & French \\
\hline FAge & $-1.5119^{* *}$ & 0.2867 & -0.1195 & $0.7885^{* *}$ \\
FGrowth & $(0.6424)$ & $(0.2002)$ & $(0.2349)$ & $(0.3303)$ \\
FLeverage & $0.2038^{* * *}$ & $0.0842^{* * *}$ & $0.1142^{* * *}$ & $0.0631^{*}$ \\
& $(0.0326)$ & $(0.0257)$ & $(0.0351)$ & $(0.0357)$ \\
FSize & $-1.8863^{* * *}$ & $-0.7886^{* * *}$ & $-0.8682^{* * *}$ & -0.6336 \\
& $(0.5323)$ & $(0.2697)$ & $(0.2730)$ & $(0.4296)$ \\
FirmGov & $0.2241^{* *}$ & -0.0333 & 0.0034 & -0.0696 \\
& $(0.1045)$ & $(0.0664)$ & $(0.0609)$ & $(0.1344)$ \\
CountryGov & -0.0637 & -0.1305 & -0.0352 & -0.1276 \\
FirmGov*CountryGov & $(0.1583)$ & $(0.1504)$ & $(0.3029)$ \\
& $(0.2110)$ & -0.0397 & -0.0542 & -0.0370 \\
Constant & $0.1724 * *$ & $(0.0384)$ & $(0.0490)$ & $(0.0561)$ \\
& $(0.0850)$ & $0.0847 * *$ & $0.0642 * *$ & 0.0945 \\
Year & 0.1000 & $(0.0353)$ & $(0.0325)$ & $(0.0882)$ \\
Country & $(0.1098)$ & $1.4823^{* *}$ & $2.3984 * * *$ & 0.0082 \\
Observations & $8.3787^{* * *}$ & $(0.6356)$ & $(0.7770)$ & $(1.1055)$ \\
$\mathrm{R}^{2}$ & $(2.2322)$ & Yes & Yes & Yes \\
\hline
\end{tabular}

Notes: This table reports the moderating effect of country governance (CountryGov) on the relationship between firm governance (FirmGov) and firm value (Tobin's Q) in emerging countries using subsampling analysis based on legal system (common law and civil law) and origin of legal system (English common law, German civil law and French civil law). Tobin's Q, firm age, firm growth, firm leverage and firm size are winsorised at $1 \%-99 \%$ levels to minimize the effect of outliers. The sample period is from 2007 to 2016 . The numbers in parentheses are standard errors. $* * *, * *, *$ denote significance of $1 \%, 5 \%$ and $10 \%$ significant levels, respectively. 


\section{Further Issue II: Subsample regression based on country}

Table 9 presents the regression analysis based on subsample by country. ${ }^{2}$ Based on descriptive statistics, there are six countries: Brazil, China, India, Korea, South Africa and Taiwan, hence the Top-6 group, which dominate $60 \%$ of the sample. Hence, we ran a subsample analysis on these six countries in a group and the rest of the emerging countries (40\%) as another group. In both groups, country governance had a significant positive moderating effect. This is aligned with the result in Table 6 . However, for the individual country estimates, we discover the moderating term is not significant for Brazil, China, India and Korea. The reason could be that these countries have poor country governance scores as provided in the descriptive statistics, except for Korea. This is consistent with our earlier findings that only better country governance has a positive moderating effect. The possible explanation of Korea having a strong country governance score, but an insignificant moderating effect may be due to the unique corporate governance structure in Korea particularly affiliated with chaebol which is shown to negatively link to firm performance (Campbell II \& Keys, 2002). On the other hand, South Africa and Taiwan both show a positive moderating effect at $5 \%$ and $10 \%$, significant levels, respectively. These may be attributed to the strong and positive country governance score in both South Africa (1.325) and Taiwan (6.057). In short, only countries with better country governance and firm governance can incur a positive effect in firm value.

\section{Conclusion}

This study examines the relationship between firm governance and firm performance in emerging countries and the moderating role of country governance. We focus on emerging countries because these countries are often characterised by low investor protection, low information transparency and inefficient capital markets (Kumar \& Zattoni, 2016). We employ panel regression to analyse 5082 firms in 21 countries over the period 2007 to 2016. The results show that firm governance is negatively linked to Tobin's Q. The fact that these emerging markets have a huge proportion of firms with poor firm governance causes the firm governance of the sample firms to have a negative relationship to firm value. We conduct subsample analysis 
Table 9: Subsample regression based on country

\begin{tabular}{|c|c|c|c|c|c|c|c|c|}
\hline & Top-6 & The rest & Brazil & China & India & Korea & $\begin{array}{l}\text { South } \\
\text { Africa }\end{array}$ & Taiwan \\
\hline FAge & $\begin{array}{l}-0.3155 \\
(0.2874)\end{array}$ & $\begin{array}{l}0.4387 \\
(0.2805)\end{array}$ & $\begin{array}{l}0.6000 \\
(0.5120)\end{array}$ & $\begin{array}{l}0.5970 \\
(0.5574)\end{array}$ & $\begin{array}{l}-0.9481 \\
(0.5829)\end{array}$ & $\begin{array}{l}0.4245 \\
(0.5000)\end{array}$ & $\begin{array}{l}-2.1449 * \\
(1.2353)\end{array}$ & $\begin{array}{l}-0.6883 * * \\
(0.3127)\end{array}$ \\
\hline FGrowth & $\begin{array}{l}0.1330^{* * *} \\
(0.0311)\end{array}$ & $\begin{array}{l}0.1324 * * * \\
(0.0336)\end{array}$ & $\begin{array}{l}-0.0046 \\
(0.0570)\end{array}$ & $\begin{array}{l}0.0751^{*} \\
(0.0391)\end{array}$ & $\begin{array}{l}0.2396^{* * *} \\
(0.0630)\end{array}$ & $\begin{array}{l}0.1068^{* * *} \\
(0.0300)\end{array}$ & $\begin{array}{l}0.1390^{* * *} \\
(0.0425)\end{array}$ & $\begin{array}{l}0.1278^{* * *} \\
(0.0421)\end{array}$ \\
\hline FLeverage & $\begin{array}{l}-0.9149^{* * *} \\
(0.2750)\end{array}$ & $\begin{array}{l}-1.4419^{* * *} \\
(0.4422)\end{array}$ & $\begin{array}{l}0.5373 \\
(0.6203)\end{array}$ & $\begin{array}{l}-0.8206 \\
(0.6211)\end{array}$ & $\begin{array}{l}-2.3652 * * * \\
(0.6795)\end{array}$ & $\begin{array}{l}-1.0610^{* * *} \\
(0.3971)\end{array}$ & $\begin{array}{l}-0.6762 \\
(0.7035)\end{array}$ & $\begin{array}{l}-0.7155^{* *} \\
(0.2963)\end{array}$ \\
\hline FSize & $\begin{array}{l}0.1127^{*} \\
(0.0577)\end{array}$ & $\begin{array}{l}-0.1838^{*} \\
(0.1096)\end{array}$ & $\begin{array}{l}-0.0057 \\
(0.2547)\end{array}$ & $\begin{array}{l}-0.1321 \\
(0.2054)\end{array}$ & $\begin{array}{l}0.1045 \\
(0.1330)\end{array}$ & $\begin{array}{l}0.0673 \\
(0.0684)\end{array}$ & $\begin{array}{l}0.4267 * * * \\
(0.1397)\end{array}$ & $\begin{array}{l}0.2453 * * \\
(0.1176)\end{array}$ \\
\hline FirmGov & $\begin{array}{l}0.1315 \\
(0.1366)\end{array}$ & $\begin{array}{l}-0.3126 \\
(0.2484)\end{array}$ & $\begin{array}{l}0.4494 \\
(0.3395)\end{array}$ & $\begin{array}{l}-0.4664 \\
(1.4214)\end{array}$ & $\begin{array}{l}-0.7437 \\
(0.6394)\end{array}$ & $\begin{array}{l}-0.1525 \\
(2.4069)\end{array}$ & $\begin{array}{l}-3.2264^{* *} \\
(1.4282)\end{array}$ & $\begin{array}{l}-2.2672 \\
(1.5436)\end{array}$ \\
\hline CountryGov & $\begin{array}{l}0.0193 \\
(0.0543)\end{array}$ & $\begin{array}{l}-0.0164 \\
(0.0480)\end{array}$ & $\begin{array}{l}2.9824^{* * *} \\
(0.8059)\end{array}$ & $\begin{array}{l}-3.6574^{* * *} \\
(0.6810)\end{array}$ & $\begin{array}{l}-4.4987 * * * \\
(0.9487)\end{array}$ & $\begin{array}{l}0.8491 * * \\
(0.3774)\end{array}$ & $\begin{array}{l}-2.1606^{*} \\
(1.1779)\end{array}$ & $\begin{array}{l}0.0690 \\
(0.1613)\end{array}$ \\
\hline \multicolumn{9}{|l|}{ FirmGov* } \\
\hline CountryGov & $\begin{array}{l}0.0702 * \\
(0.0384)\end{array}$ & $\begin{array}{l}0.1114^{*} \\
(0.0629)\end{array}$ & $\begin{array}{l}0.4824 \\
(0.4942)\end{array}$ & $\begin{array}{l}-0.2340 \\
(0.4742)\end{array}$ & $\begin{array}{l}-0.2982 \\
(0.3183)\end{array}$ & $\begin{array}{l}0.0121 \\
(0.4967)\end{array}$ & $\begin{array}{l}2.5876^{* *} \\
(0.9843)\end{array}$ & $\begin{array}{l}0.4568^{*} \\
(0.2568)\end{array}$ \\
\hline Constant & $\begin{array}{l}3.3461 * * * \\
(0.9249)\end{array}$ & $\begin{array}{l}1.3132 \\
(0.9369)\end{array}$ & $\begin{array}{l}1.8854 \\
(1.5625)\end{array}$ & $\begin{array}{l}-9.3933^{* *} \\
(3.7227)\end{array}$ & $\begin{array}{l}1.7940 \\
(2.5460)\end{array}$ & $\begin{array}{l}-3.9529 \\
(3.1007)\end{array}$ & $\begin{array}{l}12.3052 * * \\
(5.8775)\end{array}$ & $\begin{array}{l}2.9499 * * * \\
(1.0737)\end{array}$ \\
\hline Year & Yes & Yes & Yes & Yes & Yes & Yes & Yes & Yes \\
\hline Country & Yes & Yes & Yes & Yes & Yes & Yes & Yes & Yes \\
\hline Observations & 3308 & 1774 & 448 & 505 & 505 & 547 & 536 & 767 \\
\hline $\mathrm{R}^{2}$ & 0.214 & 0.2799 & 0.1278 & 0.3908 & 0.5657 & 0.1486 & 0.3563 & 0.3048 \\
\hline
\end{tabular}

Notes: This table reports the moderating effect of country governance (CountryGov) on the relationship between firm governance (FirmGov) and firm value (Tobin's Q) in emerging countries using subsampling analysis based on country. Top-6 represents the six-dominant number of firms in this sample namely Brazil, China, India, Korea, South Africa and Taiwan. The rest represents the remaining emerging countries in this sample apart from the Top-6. Tobin's Q, firm age, firm growth, firm leverage and firm size are winsorised at $1 \%-99 \%$ levels to minimize the effect of outliers. The sample period is from 2007 to 2016 . The numbers in parentheses are standard errors. ***, **, * denote significance of $1 \%, 5 \%$ and $10 \%$ significant levels, respectively.

on the top 30 and bottom 30 firms and found empirical supporting evidence of this. However, by using ROA and ROE as proxies for firm performance, we document consistent, positive and significant results with the literature. These findings are consistent with agency theory, where firms fail to practice good corporate governance, it increases the agency problem among board of directors, top management and shareholders.

Our findings also suggest that better country governance has a positive moderating effect on the relationship between firm governance and firm performance in emerging countries and the results are consistent across 
Tobin's Q, ROA and ROE. Furthermore, we find that the components of country governance such as voice and accountability, government effectiveness, regulatory quality, rule of law and control of corruption have a positive moderating effect on the relation between firm governance and firm performance. Drawing from agency theory, the results may imply that firms may not find any benefits to improving firm governance in an environment with weak country governance and a weak institutional setting (Jensen and Meckling, 1976). Institutional theory on the other hands, explains that firm governance is a result of the national institutions and social systems (Aguilera, Desender, Bednar \& Lee, 2015; Schiehll \& Martins, 2016). Our findings imply that good country governance influences firm corporate governance, this is mainly through influencing managerial and board behaviour as claimed by Kumar \& Zattoni (2016). Thus, policymakers and regulators of emerging countries should work on shaping a good country governance that is able to create more value for the firm and attract more firms to invest and operate in their countries.

\section{Acknowledgement}

This work was supported by Research University Grant (RUI) 1001/ PMGT/816307 by Universiti Sains Malaysia.

\section{Notes}

1 We thank an anonymous referee for pointing out this idea to explain the negative result between firm governance and firm value. It is indeed very insightful to explain our result.

2 We thank the anonymous referee for suggesting this idea.

\section{References}

Achim, M. V., Borlea, S. N. \& Mare, C. (2016). Corporate governance and business performance: Evidence for the Romanian economy. Journal of Business Economics and Management, 17(3), 458-474. https://doi.org/1 $0.3846 / 16111699.2013 .834841$

Adams, R. B. \& Mehran, H. (2003). Is corporate governance different for bank holding companies? Economic Policy Review, 9(1), 123-142. http:// 
dx.doi.org/10.2139/ssrn.387561

Aggarwal, R. \& Goodell, J. W. (2009). Markets and institutions in financial intermediation: National characteristics as determinants. Journal of Banking \& Finance, 33(10), 1770-1780. https://doi.org/10.1016/j. jbankfin.2009.03.004

Aguilera, R. V., Desender, K., Bednar, M. K. \& Lee, J. H. (2015). Connecting the dots: Bringing external corporate governance into the corporate governance puzzle. The Academy of Management Annals, 9(1), 483-573. https://doi.org/10.1080/19416520.2015.1024503

Aguilera, R. V., Filatotchev, I., Gospel, H. \& Jackson, G. (2008). An organizational approach to comparative corporate governance: Costs, contingencies and complementarities. Organization Science, 19, 475-492. https://doi.org/10.1287/orsc.1070.0322

Aguilera, R. V. \& Jackson, G. (2003). The cross-national diversity of corporate governance: Dimensions and determinants. Academy of Management Review, 28(3), 447-465. https://doi.org/10.5465/ amr.2003.10196772

Aguilera, R. V. \& Jackson, G. (2010). Comparative and international corporate governance. The Academy of Management Annals, 4(1), 485556. doi: 10.1080/19416520.2010.495525

Ahrens, T., Filatotchev, I. \& Thomsen, S. (2011). The research frontier in corporate governance. Journal of Management \& Governance, 15(3), 311-325. https://doi.org/10.1007/s10997-009-9115-8

Almaskati, N., Bird, R. \& Lu, Y. (2020). Corporate governance, institutions, markets and social factors. Research in International Business and Finance, 51, https://doi.org/10.1016/j.ribaf.2019.101089

Almeida, M. A. \& Zagaris, B. (2015). Political capture in the Petrobras corruption scandal: The sad tale of an oil giant. The Fletcher Forum of World Affairs, 39(2) 87-99. https://search.proquest.com/docview/17787 60902? accountid $=14645$

Alon, A. \& Hageman, A. M. (2017). An institutional perspective on corruption in transition economies. Corporate Governance: An International Review, 25(3), 155-166. https://doi.org/10.1111/corg.12199 Ammann, M., Oesch, D. \& Schmid, M. M. (2011). Corporate governance and firm value: International evidence. Journal of Empirical Finance, 18(1), 36-55. https://doi.org/10.1016/j.jempfin.2010.10.003

Anderson, A. \& Gupta, P. P. (2009). A cross-country comparison of corporate 
governance and firm performance: Do financial structure and the legal system matter? Journal of Contemporary Accounting \& Economics, 5(2), 61-79. https://doi.org/10.1016/j.jcae.2009.06.002

Arcot, S. and Bruno, V. (2007). One size does not fit all, after all: Evidence from corporate governance. 1st Annual Conference on Empirical Legal Studies. Retrived from http://dx.doi.org/10.2139/ssrn.887947

Armitage, S., Hou, W., Sarkar, S. and Talaulicar, T. (2017). Corporate governance challenges in emerging economies. Corporate Governance: An International Review, 25(3), 148-154. https://doi.org/10.1111/ corg. 12209

Bebchuk, L.A. \& Hamdani, A. (2009). The elusive quest for global governance standards. University of Pennsylvania Law Review, 157, 1263-1317. https://www.jstor.org/stable/40380267

Bhagat, S. \& Black, B. S. (2002). The non-correlation between board independence and long-term firm performance. Journal of Corporation Law, 27, 231-273. http://dx.doi.org/10.2139/ssrn.133808

Black, B. S., de Carvalho, A. G. \& Gorga, É. (2012). What matters and for which firms for corporate governance in emerging markets? Evidence from Brazil (and other BRIK countries). Journal of Corporate Finance, 18(4), 934-952. http://dx.doi.org/10.1016/j.jcorpfin.2011.10.001

Black, B. S. and Khanna, V. S. (2007). Can corporate governance reforms increase firms' market values? Event study evidence from India. Journal of Empirical Legal Studies, 4(4), 749-796. https://doi.org/10.1111/j.17401461.2007.00106.x

Bozec, R. \& Bozec, Y. (2011). The use of governance indexes in the governance-performance relationship literature: International evidence. Canadian Journal of Administrative Sciences, 29(1), 79-98. https://doi. org/10.1002/cjas.201

Brown, L. D. \& Caylor, M. L. (2004). Corporate governance study: the correlation between corporate governance and company performance. Corporate Governance Study, Institutional Shareholder Services.

Bruno, V. and Claessens, S. (2010). Corporate governance and regulation: Can there be too much of a good thing? Journal of Financial Intermediation, 19(4) 461-482. https://doi.org/10.1016/j.jfi.2009.10.001

Campbell II, T. L. \& Keys, P. Y. (2002). Corporate governance in South Korea: The chaebol experience. Journal of Corporate Finance, 8(4), 373-391. https://doi.org/10.1016/S0929-1199(01)00049-9 
Chen, J. C. \& Roberts, R. W. (2010). Toward a more coherent understanding of the organization-society relationship: A theoretical consideration for social and environmental accounting research. Journal of Business Ethics, 97(4), 651-665. https://doi.org/10.1007/s10551-010-0531-0

Chen, N. \& Yang, T. C. (2017). Democracy, rule of law and corporate governance - a liquidity perspective. Economics of Governance, 18(1), 35-70. https://doi.org/10.1007/s10101-016-0182-4

Chen, Y. R., Huang, Y. L. \& Chen, C. N. (2009). Financing constraints, ownership control and cross-border M\&As: Evidence from nine East Asian economies. Corporate Governance: An International Review, 17(6) 665-680. https://doi.org/10.1111/j.1467-8683.2009.00770.x

Cheung, Y. L., Connelly, J. T., Limpaphayom, P. \& Zhou, L. (2007). Do investors really value corporate governance? Evidence from the Hong Kong market. Journal of International Financial Management \& Accounting, 18(2), 86-122. https://doi.org/10.1111/j.1467646X.2007.01009.x

Chhaochharia, V. \& Grinstein, Y. (2007). Corporate governance and firm value: The impact of the 2002 governance rules. The Journal of Finance, 62(4), 1789-1825. https://doi.org/10.1111/j.1540-6261.2007.01257.x

Chung, K. H., Kim, J. S., Park, K. \& Sung, T. (2012). Corporate governance, legal system and stock market liquidity: Evidence around the world. Asia-Pacific Journal of Financial Studies, 41(6), 686-703. https://doi. org/10.1111/ajfs.12002

Claessens, S. and Yurtoglu, B. B. (2013). Corporate governance in emerging markets: A survey. Emerging Markets Review, 15, 1-33. http://dx.doi. org/10.1016/j.ememar.2012.03.002

Cohen, D. A., Dey, A. \& Lys, T. Z. (2008). Real and accrual-based earnings management in the pre-and post-Sarbanes-Oxley periods. The accounting review, 83(3), 757-787.

Cumming, D., Hou, W. \& Wu, E. (2014). The value of home-country governance for cross-listed stocks. The European Journal of Finance, 24(16), 1-33. https://doi.org/10.1080/1351847X.2014.917120

Cuomo, F., Mallin, C. \& Zattoni, A. (2016). Corporate governance codes: A review and research agenda. Corporate Governance: An International Review, 24(3), 222-241. https://doi.org/10.1111/corg.12148

Dahya, J., McConnell, J. J. \& Travlos, N. G. (2002). The Cadbury committee, corporate performance and top management turnover. The 
Journal of Finance, 57(1), 461-483. https://doi.org/10.1111/15406261.00428

Daily, C. M., Dalton, D. R. \& Rajagopalan, N. (2003). Governance through ownership: Centuries of practice, decades of research. Academy of Management Journal, 46(2), 151-158. https://doi.org/10.5465/30040611

De Rosa, D., Gooroochurn, N. \& Görg, H. (2015). Corruption and productivity: Firm-level evidence. Jahrbücher für Nationalökonomie und Statistik, 235(2), 115-138. http://doi.org/10.1515/jbnst-2015-0203

Denis, D. K. (2010). International corporate governance research. In H. K. Baker \& R. Anderson (eds.), Corporate governance: A synthesis of theory, research and practice. New Jersey, USA: John Wiley \& Sons, Inc.

DiMaggio, P. J. \& Powell, W. W. 1983. The iron cage revisited: Institutional isomorphism and collective rationality in organizational fields. American Sociological Review, 48, 147-160. http://doi.org/10.2307/2095101

Doidge, C., Karolyi, G. A. \& Stulz, R. M. (2004). Why are foreign firms listed in the U.S. worth more? Journal of Financial Economics, 71(2), 205-238. https://doi.org/10.1016/S0304-405X(03)00183-1

Doidge, C., Karolyi, G. A. \& Stulz, R. M. (2007). Why do countries matter so much for corporate governance? Journal of Financial Economics, 86(1), 1-39. https://doi.org/10.1016/j.jfineco.2006.09.002

Ducassy, I. \& Guyot, A. (2017). Complex ownership structures, corporate governance and firm performance: The French context. Research in International Business and Finance, 39(Part A), 291-306. http://dx.doi. org/10.1016/j.ribaf.2016.07.019

Duong, H. K., Kang, H. \& Salter, S. B. (2015). National culture and corporate governance. Journal of International Accounting Research, 15(3), 67-96. https://doi.org/10.2308/jiar-51346

Durnev, A. \& Kim, E. H. (2005). To steal or not to steal: Firm attributes, legal environment and valuation. The Journal of Finance, 60(3), 14611493. https://doi.org/10.1111/j.1540-6261.2005.00767.x

Enikolopov, R., Petrova, M. \& Stepanov, S. (2014). Firm value in crisis: Effects of firm-level transparency and country institutions. Journal of Banking \& Finance, 46, 72-84. http://dx.doi.org/10.1016/j. jbankfin.2014.04.028

Fama, E. F. \& Jensen, M. C. (1983). Separation of ownership and control. The Journal of Law and Economics, 26(2), 301-325. https://doi. 
$\operatorname{org} / 10.1086 / 467037$

Fan, J. P. H., Wei, K. C. J. \& Xu, X. (2011). Corporate finance and governance in emerging markets: A selective review and an agenda for future research. Journal of Corporate Finance, 17(2) 207-214. http:// dx.doi.org/10.1016/j.jcorpfin.2010.12.001

Faulkender, M. \& Wang, R. (2006). Corporate financial policy and the value of cash. The Journal of Finance, 61(4), 1957-1990. https://doi. org/10.1111/j.1540-6261.2006.00894.x

Fauver, L., Hung, M., Li, X. \& Taboada, A. G. (2017). Board reforms and firm value: Worldwide evidence. Journal of Financial Economics, 125(1), 120-142.

Filatotchev, I., Jackson, G. \& Nakajima, C. (2013). Corporate governance and national institutions: A review and emerging research agenda. Asia Pacific Journal of Management, 30(4), 965-986. https://doi.org/10.1007/ s10490-012-9293-9

Francis, J. R., Khurana, I. K. \& Pereira, R. (2005). Disclosure incentives and effects on cost of capital around the world, Accounting Review, 80(4), 1125-1162. https://doi.org/10.2308/accr.2005.80.4.1125

Fresard, L. (2010). Financial strength and product market behavior: The real effects of corporate cash holdings. The Journal of Finance, 65(3), 10971122. https://doi.org/10.1111/j.1540-6261.2010.01562.x

Gabriel, C. (2018). Malaysia's missing billions. Journal of Democracy, 29(1), 69-75. https:// doi:10.1353/jod.2018.0005

Gaviria, A. (2002). Assessing the effects of corruption and crime on firm performance: Evidence from Latin America. Emerging Markets Review, 3(3), 245-268. http://dx.doi.org/10.1016/S1566-0141(02)00024-9

Globerman, S. \& Shapiro, D. (2002). Global foreign direct investment flows: The role of governance infrastructure. World Development, 30(11), 18991919.

Gompers, P., Ishii, J. \& Metrick, A. (2003). Corporate governance and equity prices. The Quarterly Journal of Economics, 118(1), 107-155. https://doi. org/10.1016/S0305-750X(02)00110-9

González, J. S. \& García-Meca, E. (2014). Does corporate governance influence earnings management in Latin American markets?. Journal of Business Ethics, 121(3), 419-440.

Han, B., Wang, S., Wan, Y., Liu, J., Zhao, T., Cui, J. \& Cui, F. (2019). Has the public lost confidence in vaccines because of a vaccine scandal 
in China. Vaccine, 37(36), 5270-5275. https://doi.org/10.1016/j. vaccine.2019.07.052

Hanousek, J. \& Kochanova, A. (2016). Bribery environments and firm performance: Evidence from CEE countries. European Journal of Political Economy, 43, 14-28. https://doi.org/10.1016/j. ejpoleco.2016.02.002

Helmke, G. \& Levitsky, S. (2004). Informal institutions and comparative politics: A research agenda. Perspectives on Politics, 2(4), 725-740. doi: 10.1017/S1537592704040472

Holmstrom, B. \& Kaplan, S. N. (2003), The State of U.S. corporate governance: What's right and what's wrong?. Journal of Applied Corporate Finance, 15, 8-20. https://doi.org/10.1111/j.1745-6622.2003. tb00457.x

Jalilian, H., Kirkpatrick, C. \& Parker, D. (2007). The impact of regulation on economic growth in developing countries: A cross-country analysis. World development, 35(1), 87-103. https://doi.org/10.1016/j. worlddev.2006.09.005

Judge, W. Q., Gaur, A. \& Muller-Kahle, M. I. (2010). Antecedents of shareholder activism in target firms: Evidence from a multi-country study. Corporate Governance: An International Review, 18(4), 258-273. https://doi.org/10.1111/j.1467-8683.2010.00797.x

Lee, H. J. \& Cho, I. (2016) Corporate governance and corporate bond liquidity, Global Economic Review, 45(2), 189-205, doi: 10.1080/1226508X.2015.1137483

Kaufmann, D., Kraay, A. \& Mastruzzi, M. (2009), Governance matters VIII: Aggregate and individual governance indicators 1996-2008. Washington, DC: The World Bank.

Kim, E. H. \& Lu, Y. (2013). Corporate governance reforms around the world and cross-border acquisitions. Journal of Corporate Finance, 22, 236253. http://dx.doi.org/10.1016/j.jcorpfin.2013.05.005

Kim, Y. U. \& Ozdemir, S. Z. (2014). Structuring corporate boards for wealth protection and/or wealth creation: The effects of national institutional characteristics. Corporate Governance: An International Review, 22(3), 266-289. https://doi.org/10.1111/corg.12062

Klapper, L. F. \& Love, I. (2004). Corporate governance, investor protection and performance in emerging markets. Journal of Corporate Finance, 10(5), 703-728. http://dx.doi.org/10.1016/S0929-1199(03)00046-4 
Klein, P., Shapiro, D. \& Young, J. (2005). Corporate governance, family ownership and firm value: The Canadian evidence. Corporate Governance: An International Review, 13(6), 769-784. https://doi. org/10.1111/j.1467-8683.2005.00469.x

Kumar, P. \& Tsetsekos, G. P. (1999). The differentiation of 'emerging' equity markets. Applied Financial Economics, 9(5), 443-453. https://doi. org/10.1080/096031099332104

Kumar, P. \& Zattoni, A. (2013). How much do country or firmlevel variables matter in corporate governance studies? Corporate Governance: An International Review, 21(3), 199-200. https://doi. org $/ 10.1111 /$ corg. 12025

Kumar, P. \& Zattoni, A. (2016). Institutional environment and corporate governance. Corporate Governance: An International Review, 24(2), 82-84. https://doi.org/10.1111/corg. 12160

La Porta, R., Lopez-de-Silanes, F. \& Shleifer, A. (2008). The economic consequences of legal origins. Journal of Economic Literature, 46(2), 285-332. http://dx.doi.org/10.1257/jel.46.2.285

La Porta, R., Lopez-de-Silanes, F., Shleifer, A. \& Vishny, R. W. (1997). Legal determinants of external finance. The Journal of Finance, 52(3), 1131-1150. https://www.jstor.org/stable/2329518

La Porta, R., Lopez-de-Silanes, F., Shleifer, A. \& Vishny, R. W. (1998). Law and finance. Journal of Political Economy, 106(6), 1113-1155. https:// www.jstor.org/stable/10.1086/250042

La Porta, R., Lopez-de-Silanes, F., Shleifer, A. \& Vishny, R. W. (2000). Investor protection and corporate governance. Journal of Financial Economics, 58(1-2), 3-27. https://doi.org/10.1016/S0304405X(00)00065-9

La Porta, R., Lopez-de-Silanes, F., Shleifer, A. \& Vishny, R. W. (2002). Investor protection and corporate valuation. The Journal of Finance, 57(3), 1147-1170. https://doi.org/10.1111/1540-6261.00457

Larcker, D. F., Richardson, S. A. \& Tuna, I. R. (2007). Corporate governance, accounting outcomes and organizational performance. The Accounting Review, 82(4), 963-1008. https://doi.org/10.2308/ accr.2007.82.4.963

Lim, J., Makhija, A. K. \& Shenkar, O. (2016). The asymmetric relationship between national cultural distance and target premiums in crossborder M\&A. Journal of Corporate Finance, 41, 542-571. https://doi. 
org/10.1016/j.jcorpfin.2016.07.007

Lin, H. P., Walker, M. M. \& Wang, Y. J. (2020). Shareholder wealth effects of corporate fraud: Evidence from Taiwan's securities investor and futures trader protection act. International Review of Economics \& Finance, 65, 222-243. https://doi.org/10.1016/j.iref.2019.09.010

Luo, Y. (2002). Multinational enterprises in emerging markets. Copenhagen Business School Press DK.

Maher, M. \& Andersson, T. (2000). Corporate governance: Effects on firm performance and economic growth. http://dx.doi.org/10.2139/ ssrn. 218490

Michelberger, K. (2016). Corporate governance effects on firm performance: A literature review. Regional Formation and Development Studies, 20(3), 84-95.

Morey, M., Gottesman, A., Baker, E. \& Godridge, B. (2009). Does better corporate governance result in higher valuations in emerging markets? Another examination using a new data set. Journal of Banking \& Finance, 33(2), 254-262. https://doi.org/10.1016/j.jbankfin.2008.07.017

Munisi, G. \& Randøy, T. (2013). Corporate governance and company performance across Sub-Saharan African countries. Journal of Economics and Business, 70, 92-110. https://doi.org/10.1016/j. jeconbus.2013.08.003

Narayanaswamy, R., Raghunandan, K. \& Rama, D. V. (2012). Corporate governance in the Indian context. Accounting Horizons, 26(3), 583-599. https://doi.org/10.2308/acch-50179

Natalia, O., Javier, A. \& Matilde, M. (2016). Corporate governance and environmental sustainability: The moderating role of the national institutional context. Corporate Social Responsibility and Environmental Management, 23(3), 150-164. https://doi.org/10.1002/csr.1367

Ngobo, P. V. \& Fouda, M. (2012). Is 'Good' governance good for business? A cross-national analysis of firms in African countries. Journal of World Business, 47(3), 435-449. https://doi.org/10.1016/j.jwb.2011.05.010

Nguyen, T., Locke, S. \& Reddy, K. (2015). Ownership concentration and corporate performance from a dynamic perspective: Does national governance quality matter?. International Review of Financial Analysis, 41, 148-161. https://doi.org/10.1016/j.irfa.2015.06.005

North, D. C. (1990). Institutions, institutional change and economic performance. Cambridge: Oxford University Press. 
O’Connor, T., Kinsella, S. \& O'Sullivan, V. (2014). Legal protection of investors, corporate governance and investable premia in emerging markets. International Review of Economics \& Finance, 29, 426-439.

Oehmichen, J., Schrapp, S. \& Wolff, M. (2017). Who needs experts most? Board industry expertise and strategic change-a contingency perspective. Strategic Management Journal, 38(3), 645-656. https://doi.org/10.1002/ smj. 2513

Qian, X., Cao, T. \& Cao, C. (2018). Institutional environment and bank loans: Evidence from 25 developing countries. Corporate Governance: An International Review, 26(2), 84-96. https://doi.org/10.1111/ corg. 12197

Renders, A., Gaeremynck, A. \& Sercu, P. (2010). Corporate-governance ratings and company performance: A cross-European study. Corporate Governance: An International Review, 18(2), 87-106. https://doi. org/10.1111/j.1467-8683.2010.00791.x

Sami, H., Wang, J. \& Zhou, H. (2011). Corporate governance and operating performance of Chinese listed firms. Journal of International Accounting, Auditing and Taxation, 20(2), 106-114. https://doi. org/10.1016/j.intaccaudtax.2011.06.005

Sayari, N. \& Marcum, B. (2018). Reducing risk in the emerging markets: Does enhancing corporate governance work?. BRQ Business Research Quarterly, 21(2), 124-139. https://doi.org/10.1016/j.brq.2018.01.002

Schiehll, E. \& Martins, H. C. (2016). Cross-national governance research: A systematic review and assessment. Corporate Governance: An International Review, 24(3), 181-199. https://doi.org/10.1111/corg.12158 Scott, W. R. (2013). Institutions and organizations: Ideas, interests and identities (2nd ed.). Thousand Oaks, CA: Sage Publications.

Seifert, B. \& Gonenc, H. (2018). The effects of country and firm-level governance on cash management. Journal of International Financial Markets, Institutions and Money, 52, 1-16.

Shleifer, A. \& Vishny, R. W. (1997). A survey of corporate governance. The Journal of Finance, 52(2), 737-783. https://doi. org/10.1111/j.1540-6261.1997.tb04820.x

Siddiqui, S. S. (2015). The association between corporate governance and firm performance - A meta-analysis. International Journal of Accounting and Information Management, 23(3), 218-237. http://doi:10.1108/ IJAIM-04-2014-0023 
Stulz, R. M. \& Williamson, R. (2003). Culture, openness and finance. Journal of financial Economics, 70(3), 313-349.

Terdpaopong, K. \& Trimek, J. (2015). Financial scandal: The case of King Mongkut's Institute of Technology Ladkrabang, Thailand. Procedia Economics and Finance, 28, 39-45. https://doi.org/10.1016/S22125671(15)01079-5

Wilson, R. (2016). Does governance cause growth? Evidence from China. World Development, 79, 138-151. http://dx.doi.org/10.1016/j. worlddev.2015.11.015

Tsipouri, L. \& Xanthakis, M. (2004). Can corporate governance be rated? Ideas based on the Greek experience. Corporate Governance: An International Review, 12(1), 16-28. https://doi.org/10.1111/j.14678683.2004.00340.x

Wintoki, M. B., Linck, J. S. and Netter, J. M. (2012). Endogeneity and the dynamics of internal corporate governance. Journal of Financial Economics, 105(3), 581-606. https://doi.org/10.1016/j.jfineco.2012.03.005 Zattoni, A. \& Cuomo, F. (2008). Why adopt codes of good governance? A comparison of institutional and efficiency perspectives. Corporate Governance: An International Review, 16(1), 1-15. https://doi. org/10.1111/j.1467-8683.2008.00661.x 